\title{
Król w dawnej Polsce w świetle dokumentów praktyki sqqdowej
}

\section{Der König im Lichte der altpolnischen Gerichtspraxis}

1. Wstęp. 2. Król a miasta (Gdańsk). 3. Król a duchowieństwo. 4. Król a szlachta. 5. Reasumpcja.

1. Einleitung. 2. Der König und der Bürgerstand (in Danzig). 3. Der König und die Geistlichkeit. 4. Der König und der Adel. 5. Resümee.

1. W niniejszym artykule zostaly sumarycznie zebrane dotychczasowe cząstkowe ustalenia autora, dotyczące roli króla w sferze wymiaru sprawiedliwości, w niewielkim stopniu uzupelnione dodatkowymi informacjami.

Glówny trzon źródeł stanowią archiwalia gdańskie, częściowo toruńskie (XVI-XVIII w.) ${ }^{1}$, akta kapitulne i konsystorskie (1403-1533) ${ }^{2}$, oraz małopolskie księgi sądowe ziemskie i grodzkie, wydane przez Antoniego Z. Helcla $(\mathrm{XIV}-\mathrm{XVI} \text { w. })^{3}$.

\footnotetext{
' Z. R y maszewski, Instrukcje syndyków gdaniskich $w$ sprawach rozpoznawanych przed sqdami zadwornymi (od końca XVI do poczqtku XVIII w.), Czasopismo Prawno-Historyczne [CPH] 1985, t. 37, z. 2, s. 187-206; t en że, Ius informandi Gdańska w epoce nowożytnej (koniec XVI - poczqtki XVIII wieku), Acta Universitatis Lodziensis [AUL] 1986, Folia Iuridica 21, s. 93-134; t enże, Sprawy gdańskie przed sqdami zadwornymi oraz ingerencja królów w gdański wymiar sprawiedliwości XVI-XVIII w., Wrociaw 1985; t e n że, Trzy wyroki sqdów zadwornych $w$ kwestii prawa reprezentacji wśród krewnych bocznych $w$ miejskim prawie spadkowym, Acta Universitatis Nicolai Copernici [AUNC] 1990, Prawo XXX, Nauki Humanistyczno-Społeczne, z. 218, s. 83-97; t e nże, $O$ prawie miejskim $w$ średniowiecznej Polsce, [w:] Wielkie miasto. Czynniki integrujqce $i$ dezintegrujqce, Lódź 17-19 maja 1994 r., t. I, Łódź 1995, s. 26-33.

${ }^{2}$ Z. R y maszewski, O stosunkach miedzy Państwem a Kosiciolem $w$ Polsce $w$ świetle akt kapitulnych $i$ konsystorskich z lat 1403-1533, AUL 1993, Folia Iuridica 56, s. 53-89.

${ }^{3} \mathrm{Z}$. R y mas zewski, ,Domino Regi perpetuum silentium imponimus". Król w malopolskich zapiskach sqdowych, [w:] Studia z historii panistwa, prawa i idei. Prace dedykowane Profesorowi Janowi Malarczykowi, Lublin 1997, s. 311-324.
} 
W takiej kolejności ukazywały się prace autora i ten układ chronologiczny zachowujemy $w$ niniejszym artykule. Odpowiada on podziałowi stanowemu dawnej Polski, aczkolwiek jest niezgodny z porządkiem hierarchicznym ${ }^{4}$.

Geneza zainteresowań autora tą problematyką ma starą metrykę. Już od końca lat pięćdziesiątych, jeszcze na seminarium Jana Adamusa, w trakcie przygotowywania monografii niedziału rodzinnego i prawa bliższości krewnych, uczestnicy seminarium bywali zaskakiwani informacjami źródłowymi, w których monarcha jawił się jako niemal wszechwładny. Ze strony Jana Adamusa szły ostrożne zachęty do zainteresowania się rolą monarchy w dawnej Polsce, ostrożne, bowiem Jan Adamus słusznie obawiał się, że początkujący adepci moga nie podołać tej bardzo trudnej problematyce. Barbara Waldo po napisaniu monografii niedziału, właściwie szybko zaniechała pracy naukowej, z wielką szkodą dla nauki polskiej, był to bowiem nieprzeciętny talent, o umyśle bardzo precyzyjnym. Autor niniejszego artykułu $\mathrm{z}$ kolei ugrzązł na kilkanaście lat $\mathrm{w}$ studiach nad źródłami prawa saskiego w Polsce.

Problem roli króla wypłynąl nieoczekiwanie $w$ trakcie przeglądania archiwaliów gdańskich, dostarczonych przez Zbigniewa Zdrójkowskiego, który właśnie organizowal zespół do prac nad prawem chelmińskim. Okazało się, że te źródła zawierają stosunkowo niewiele informacji o prawie chełmińskim, jest $\mathrm{w}$ nich natomiast wiele dowodów ingerencji króla $w$ sprawy gdańskie.

Gdańsk nie był $\mathrm{z}$ pewnością typowym miastem dawnej Polski. Przypomnijmy jednakże najpierw, co generalnie, gdy idzie o miasta królewskie, leżało $w$ gestii władcy. Przede wszystkim jest on właścicielem miasta. On zazwyczaj mianuje członków władz miejskich, rozstrzyga spory między patrycjatem a pospólstwem. Dokonuje w związku z tymi konfliktami reorganizacji władz miejskich albo ją zatwierdza. Ingeruje bezpośrednio w stosunki miejskie, wydając akty prawne (statuty, ordynacje itp.). Pilnuje przy tym, by mu w tę gestię nie wkraczał sejm. Król jest dla miast źródłem prawa, wprowadza nowe lub modyfikuje dotychczasowe instytucje prawne,

\footnotetext{
${ }^{4}$ Stanowy charakter sądów w badanym przez nas okresie jest dosyć problematyczny. Sądy nie badały $z$ urzędu kwestii właściwości, ew. zarzuty podnosily strony. W sądach kościelnych spotyka się niekiedy procesy między osobami świeckimi o dobra ziemskie. W sądach szlacheckich nie brak osób duchownych, chłopów. Hierarchowie kościelni zasiadają w sądach królewskich (Lęcz. I, 5938 z 1399 r.), przewodniczą tym sądom (Leksz. II, 1233 z 1399 r., Gniezno, presente Domino rege). Jako strony procesowe duchowni bynajmniej nie korzystaja z żadnej taryfy ulgowej, np. biskupi przysięga dowodza swych racji (U1. II, CCLXV (6) z 1398 r.), duchowni swą nieobecność w sądzie usprawiedliwiają świadectwem spowiedzi (Ul. II, CCLXVIII (80), (107) z 1398 r.), kapituła toczy proces z biskupem (UI. I, 5208 z 1398 r.).
} 
często na prośbę miast ${ }^{5}$. Jako właściciel ma określone interesy majątkowe w mieście, nad którymi czuwa burgrabia, starosta lub wojewoda, a o które dbają też sami mieszczanie, spiesząc gorliwie $\mathrm{z}$ wieściami o ich naruszeniu. Do króla należy wykładnia autentyczna przywilejów i innych aktów prawnych. Sądownictwo należy do miasta, ale od wyroków sądów miejskich można odwołać się do króla, to jest do Asesorii Koronnej, następnie do Sądu Relacyjnego. W obu tych judykaturach królewskich czynnik miejski nie jest reprezentowany, stąd $w$ nauce jurysdykcja tych sądów w sprawach miejskich bywa oceniana jako wyraz supremacji szlachty nad mieszczaństwem, co jest niewątpliwie zbytnim uproszczeniem.

2. Przechodzimy obecnie na grunt stosunków Gdańsk - król. Ingerencja królów w sprawy gdańskie była bardzo silna $\mathrm{i}$ wielokierunkowa. Królowie nader często ingerują $w$ procesy sądowe, wydają szereg pism ad favorem. Poddani przy tym zwracają się do nich w najróżniejszych sprawach, często naprawdę błahych ${ }^{6}$.

Król jest supremus omnium puppillorum in Regno Nostro patronus ${ }^{7}$, wkracza więc $w$ sprawy opiekuńcze. Jako opiekun także wdów, bierze je często w obronę. Ingeruje $w$ system dowodów. Szereg dzialań ma wyraźnie charakter protekcji królewskiej. Dalej, władca korzysta z prawa laski, uwalnia od kary cudzolożników, którzy uciekając przed wielką $w$ tej materii surowością prawa miejskiego, udają się pod opiekę Kościoła (także luteranie). Tam spowiadają się $\mathrm{i}$ odbywają pokutę, a król zgodnie $\mathrm{z}$ zasadą ne bis in eadem uznaje, że zostali już ukarani i odrzuca pretensje miasta.

Wbrew Tractatus portorii królowie udzielają glejtów w sprawach cywilnych, szeregu reskryptów, odwlekających wykonanie wyroku. Wiele jest listów moratoryjnych, zakazanych skądinąd przez szereg aktów. Królowie naruszali prawa miasta przy okazji potwierdzania przywilejów, szafowali egzempcjami itd. $^{8}$

Gdańsk protestuje. Pierwszych dziesięć lat panowania Zygmunta III Wazy - to okres nieustannych zmagań Gdańska z królem. Miasto odmawia

\footnotetext{
SKodeks Dyplomatyczny Wielkopolski [KDW] VII, 783 z 1416 r. Jagiełlo ustala zasady dziedziczenia przez dzieci po rodzicach ruchomości należących do mieszczan poznańskich. Z 1615 r. pochodzi gdańska zapiska o orzeczeniu przez króla w kwestii prawa reprezentacji: SRM tas eo attento, quod inter partes de jure representativo non in primo gradu linaee collateralis, sed in alteriori agitur, ideo sentenciam Chencinensem retractata, Juris Supremi Magdeburgensis sententiam approhavit. (Sąd krakowski orzekł, że powodowie są o jeden stopień dalsi w pokrewienstwie ze zmarłą, wobec czego ich żądanie dopuszczenia do spadku oddalil). WAP Gdańsk, sygn. 300 R/T 4, Observationes Gedanenses, s. 283.

' Zob. Z. R y maszewski, Spravy gdañskie..., s. 167; t e nże, Ius informandi..., s. 108 i n.

Zob. Z. R y ma s zew ski, Sprawy gdańskie..., s. 162 i ods. 22.

${ }^{3}$ Zob. ibidem, s. $163 \mathrm{i} \mathrm{n}$.
} 
egzekucji wyroków królewskich, odmawia wydania akt stronom odwolującym się do Asesorii Koronnej, nieustannie przypomina o swych przywilejach. Królowi jednak udalo się zlamać opór miasta. Po Zygmuncie Wazie ingerencji królewskich jest nadal tak wiele, wymagają one od Gdańska nieustannej korespondencji, że w $1677 \mathrm{r}$. miasto już zbiorowo protestuje przeciwko wszelkiego rodzaju serwitoriatom, faktoriatom, egzempcjom i protekcjom?.

Równolegle wszelako występuje inne zjawisko, mianowicie Gdańsk darzy króla jako sędziego pełnym zaufaniem, i od niekorzystnych wyroków Asesorii Koronnej masowo odwołuje się do Sądu Relacyjnego - tego $\mathrm{z}$ sądów zadwornych, w którym król zasiada sua persona ${ }^{10}$.

Dalej, król jest dla Gdańska źródłem prawa, viva lex ${ }^{11}$. Nie kwestionuje się jego prawa do wydawania ordynacji uzupełniających, a nawet zmieniających prawo miejskie, oraz do dokonania wykladni autentycznej przywilejów. Owe przywileje są zresztą przez króla nagminnie łamane. Zmienność, a nie stałość charakteryzuje stosunki panujące między Gdańskiem a królem.

Jeszcze jedna rzecz uderza; otóż król jest dokładnie i szybko informowany przez, jakbyśmy dziś powiedzieli, obywatelsko nastawionych mieszczan o każdym kaduku, każdym naruszeniu jego własności, interesów, o zaległościach podatkowych itp. Jest na bieżąco informowany, jak miasto realizuje jego polecenia, jakie jest nastawienie władz miejskich względem jego osoby.

Rzecz o stosunkach panujących między Gdańskiem a monarchą zakończyliśmy zdaniem następującym: ,Z lektury naszego materiału wynosi się nieodparte przekonanie, że ręka królewska w tym mieście była na co dzień, niczym w absolutum dominium, niemal bezpośrednio odczuwalna". Podtrzymujemy tę opinię.

Jeśli tak bylo z Gdańskiem, największym i najbogatszym miastem polskim, jak mogły kształtować się stosunki między innymi miastami a monarchą? Czy ich zależność od władcy nie była większa? A jak rzecz się miała $z$ innymi stanami? Otóż wyniki lektury akt kapitulnych $i$ konsystorskich $\mathrm{z}$ lat $1403-1533$ są podobne ${ }^{12}$.

${ }^{9}$ Zob. ibidem, s. $166 \mathrm{i} \mathrm{n.}$

${ }^{10}$ Zob. Z. Rymaszewski, Instrukcje..., s. 196, 202-203. Zob. też ods. 111 na s. 202: Czasem w jednej instrukcji poleca się kilkakrotnie, w przypadku odrzucenia kolejno każdej $z$ podniesionych ekscepcji, apelować do króla...

$"$ Jest to prerogatywa królewska, $z$ której monarcha nie musi korzystać. Zob. Z. R y m a s zew s ki, Instrukcje..., s. 202, ods. 107 z s. 201. Król jest źródłem prawa sądowego dla wszystkich miast królewskich, zob. Z. R y m a z zewski, Trzy wyroki...

${ }^{12}$ Zob. Z. R y mas zew ski, O stosunkach... 
3. I tu król ingeruje w procesy toczone w sądach kościelnych ${ }^{13}$, monituje, wystawia listy inhibicyjne, każe znieść interdykt ${ }^{14}$, także ekskomunikę ${ }^{15}$, korzysta z prawa ewokacji, przy czym taką ewokowaną sprawę rozpatruje niekiedy wespól z biskupem czy arcybiskupem ${ }^{16}$.

Funkcjonuje ius spolii, w czasie wakansu na stolcu biskupim król bierze "W opiekę" dobra biskupie. Pominiemy tu spory o dziesięcinę, jako rzecz powszechnie znaną. Król ingeruje $w$ wybór biskupa przez kapitułę. On obsadza co najmniej 90 kanonii w kapitułach i kolegiatach. Ci ludzie jemu zawdzięczają wyniesienie i przynajmniej część z nich o tym pamięta - państwo (także kościół) donosami stoi, rzecz to znana i nie ograniczona tylko do jednej epoki.

Do króla udawano się o wstawiennictwo, gdy odczuwano jako niesprawiedliwe decyzje różnych agend kościelnych. Sądząc ze źródel, przyczyn do szukania pomocy u króla było sporo ${ }^{17}$.

Akta kościelne pelne są wzmianek o nieustannym szukaniu tego wsparcia, i to w sprawach przeróżnych. Nieraz w kwestiach naprawdę drobnych wysłannicy kapitul jeżdżą za królem po calym rozleglym obszarze Rzeczypospolitej Obojga Narodów. Ileż jest pism królewskich wydawanych in loco campestri. Ciągną za monarchą cake tabuny petentów upraszających laski, oczywiście nie za darmo. A podarki otrzymuje nie tylko król. By stanąć przed obliczem króla, trzeba było prosić o pomoc niejednego dworzanina, a i samego kanclerza. Wydatki z tym związane są skrupulatnie notowane w księgach kościelnych.

${ }^{13} \mathrm{KDW}$ VII, 520 z $1404 \mathrm{r}$. Mieszczanin poznański jest pozwany przez kanonika włocławskiego o dom przed sąd oficjała. Król nakazuje odesłać strony ad ius nostrum seculare [...] ne statuta Regni nostri per Vos non infringantur.

KDW VII, 526 z 1404 r. List inhibicyjny króla do oficjała gnieźnieńskiego, by z rozpatrzeniem sporu o dziesięcinę wstrzymał się do przybycia króla do Gniezna, podobnie KDW IX, 1249 z 1430 r.: król każe oficjałowi gnieźnieńskiemu odłożyć sprawę przeciwko synom pewnego szlachcica do swego przyjazdu.

KDW IX, 1327 z 1433 r. - król nakazuje oficjalowi gnieźnieńskiemu oddalić pretensje proboszcza z Dziekanowic do wsi Góra. Wieś należy do proboszcza z Węglewa, a król ma prawo patronatu w kościele wẹglewskim.

KDW VIII, 997 z 1424 r., proces o konia i woźnicẹ. Król nakazuje oficjałowi gnieźnieńskiemu odłożyć sprawę przeciwko Paszkowi z Gosławic do swego przyjazdu. (Paszek - olim marschalcus arcybiskupa gnieźnieńskiego, powodami są wikariusze gnieźnieńscy).

${ }^{14}$ Zob. Z. R y m a s zewski, O stosunkach..., s. 77. Zob. też KDW VII, 526 z 1404 r.

is KDW VII, 517 z 1404 r.; KDW IX, 1262 z $1431 \mathrm{r}$.

${ }^{16}$ Z. R y maszewski, O stosunkach..., s. 80-81, pkt 13.4. W Helc. II, 3649 z 1460 r. król wraz ze Zbigniewem Oleśnickim rozpatrują skargę chłopów poddanych klasztoru staniąteckiego o nadmierne ciężary. W KDW IX, 1249 z 1430 r. król poleca arcybiskupowi gnieźnieńskiemu i staroście generalnemu wielkopolskiemu, by rozsądzili spór między mieszczanami poznańskimi.

${ }^{17}$ Np. gdy stolec biskupi wakował, król zakazywał wszystkim urzędnikom Korony pozywania ludzi biskupstwa, np. poznańskiego - KDW X, 1442 z 1437 r. W KDW VIII, 963 z 1423 r. król donosi generałowi karmelitów o rozprzężeniu panującym w klasztorze Bożego Ciała w Poznaniu i prosi o ustanowienie tam przeorem brata Andrzeja. 
Odnosi się wrażenie, że król chętnie dawał posłuchanie swym poddanym. Dzięki temu pogłębiała się jego wiedza o tym, co się $w$ kraju dzieje, a i skarbiec zapełnial się podarkami. Odnosi się też nieodparte wrażenie, że kościół polski w XV-XVI stuleciach nie jest wprawdzie Staatskirche, ale $z$ pewnością jest to Königskirche ${ }^{18}$.

4. Pozostał nam jeszcze stan w Polsce dawnej najważniejszy - stan szlachecki. Pod interesującym nas kątem przejrzeliśmy głównie wydany przez A. Z. Helcla wybór malopolskich zapisek sądowych ${ }^{19}$. Zastrzec trzeba, że ze względu na częstą w Małopolsce obecność króla mogły tu być sytuacje specyficzne, dlatego nie zamierzamy uzyskanych wyników traktować jako miarodajnych dla całej Korony ${ }^{20}$. Nie odbiegają one jednak od tego, co zaobserwowaliśmy w aktach gdańskich i kościelnych.

I tu ingerencja króla jest bardzo znaczna. Pełno jest listów inhibicyjnych, mandatów, monitów, ewokacji, ustanawiania sądów komisarskich. W związku $\mathrm{z}$ tym może warto przypomnieć, że owe listy inhibicyjne, mandaty, monity itd. kancelaria królewska wydawała nie badając, czy prośby petentów są zasadne ${ }^{21}$.

$\mathrm{O}$ ile w Gdańsku napotykały one na opór władz miasta (dysponujących odpowiednim aparatem urzędniczym) ${ }^{22}$, a w sądach kościelnych strona procesowa dotknięta ingerencją królewską niemal zawsze protestowała ${ }^{23}$, o tyle wśród szlachty protesty są raczej rzadkie ${ }^{24}$. Szlachta znalazła środek dogodniejszy, mianowicie stosowała klauzulę umowną, wykluczającą odwoływanie się do króla ${ }^{25}$.

Z drugiej strony jest wiele próśb o odesłanie sprawy do króla, co można interpretować jako wyraz zaufania do monarszego poczucia sprawiedliwości ${ }^{26}$.

i8 Zob. Z. R y mas zew ski, O stosunkach..., s. 88-89.

19 Tylko okazjonalnie przytaczamy informacje $z$ innych regionów.

${ }^{20}$ Oto kilka dowodów ingerencji króla $\mathrm{z}$ ksiąg sądowych łęczyckich: Lęcz. I: 286, 287 z 1387 r.; 763 z 1388 r.; 1935 z 1391 r.; 4791 z 1400 r.; 5538 z 1398 r.; Łęcz. II: 3378 z 1410 r.; 3409, 3445, 3455, 3457 z 1419 r.; 4478 z 1393 r.

${ }^{21}$ Zob. Z. R ymaszewski, „Domino Regi...", s. 318, tamże w odsyłaczu 20 literatura do tej kwestii. W Helc. II, 4413 z 1439 r. wyhudzenie pisma królewskiego (w trakcie trwania procesu). Sąd: Semota primum prefata littera Regie Maiestatis nociva contra inscripciones et munimenta (strony przeciwnej) odsyła do innego sądu.

${ }^{22}$ Patrz wyżej, s. 174.

${ }^{23} \mathrm{Z}$. R y maszew ski, O stosunkach..., s. 83. Ów protest jest zazwyczaj wyrażony za pomocą formularzowego zwrotu protestante de gravamine et defectu iustitie et appellando.

${ }^{24}$ Zob. Z. R y maszewski, „Domino Regi...", s. 319 i n. Zazwyczaj czytamy Et nos littere Regie obedivimus, Akty grodzkie i ziemskie z czasów Rzeczypospolitej Polskiej, t. I-XXV, Lwów 1868-1935 [AGZ] XIII, 1070 z 1439 r.

is Zob. Z. R y m as zewski, „Domino Regi...”, s. 321.

${ }^{26} \mathrm{~W}$ Helc. II, $4520 \mathrm{z} 1500 \mathrm{r}$. strony spierają się o to, czy sprawa została odesłana ad iudicium Curie Regie Maiestatis czy ad Regiam Maiestatem. Sạd skierował pytanie do króla (ad Regiam Maiestatem). 
Nader częste są przypadki kierowania przez sądy zapytań do króla - ad interrogandum.

I remisje, i interrogacje powinny stać się przedmiotem odrębnych badań. Tu także obok spraw istotnie zawiłych ${ }^{27}$ spotykamy, szczególnie w AGZ, sporo zapytań w sprawach, które odbieramy jako błahe.

W sądach szlacheckich król bywa uczestnikiem procesu, przy czym występuje w nich w rolach dwojakich: a) jest strona w sprawach prywatnych (np. jako właściciel dóbr); b) król dochodzi swych uprawnień władczych (publicznych) na drodze zwyklego procesu sądowego ${ }^{28}$.

Do przykładów podanych w artykule Domino Regi... dorzucić możemy kilka dalszych:

a) król jako osoba prywatna:

- toczy proces w $1405 \mathrm{r}$. o jezioro lednickie.

Pozn. 2382. Item dominus Mroczko subiudex Poznaniensis ducit testes contra dominum regem pro lacu Lednicza [...] iaco to swatczø, yaco Micolay Gorski potsandek lowil letnim lowem na yeszerze Ledniczi za crola Kazimira y po crolu Kazimirze.

W 2424 z 1405 r. Mroczko przeprowadził dowód ze świadków.

- w 1450 r. król przegrywa proces o wójtostwo lubelskie przed sądem komisarskim (jako powód), przy czym sąd orzeka m. in. ipsique domino Regi silencium perpetuum imponentes (Helc. II, 3421).

- w 1490 r. król wytacza proces Zofii, żonie Jana z Oporowa, wojewody brzeskiego, którą pozywa (nie wiemy o co) ad Convencionem generalem. Wyniku procesu nie znamy (Helc. II, 4359).

- w 1498 r. król (jego pełnomocnik) przypowieszcza pozwanego w sprawie o 3000 grzywien, przy czym pozwany zarzuca przypowiastowi wadliwość: Et primo, quia Regia Maiestas in concitacione ad satisfaciendum, magis quam citacio capitalis obloquitur, et discordant; et hoc isto, quia in citacione stat "Osthresznycza", et in concitacione stat „Osthransznycza”, nomen ville, pro qua causa ad presens vertitur. Et eciam magis concitavit, quam in citacione originali continetur, et hoc isto, quia in citacione non est nomen proprium "Nicolaus", et in concitacione est additum hoc nomen "Nicolaus", qui Nicolaus debuit iurare pro eadem hereditate, pro qua causa vertitur; et ideo est magis

${ }_{27}$ Zob. np. Helc. II: 4448 z 1495 r. i 4457 z 1497 r.

${ }^{28}$ Zob. Z. R y m aszewski, „Domino Regi...", s. 322. W naszych rozważaniach pomijamy czynności króla dotyczące organizacji sądów, obsadzania stanowisk. Mamy wszelako przykłady reakcji króla na obejmowanie funkcji bez jego zgody:

- Łęcz. II, 3835 z 1391 (castr.) It. Iczko Mirzwa tenetur penam, quod recepit officium absque licencia regis.

- Łęcz. II, 3836 z 1391 r. (castr.) It. Jasko famulus Puczkonis tenetur penam sex marcarum, quod recepit officium absque licencia regis. 
(in) concitacione quam citatione, et ob hanc indebitam et inconsuetam concitationem peto remissionem, aut quid iuris est.

Pelnomocnik króla dowodzi: Quia si summa esset variata aut multiplicata, tunc esset magis concitatum quam citatum. Sed summa concordat in citatione et concitacione, ergo non est magis concitatum quam citatum. Pozwany pozostaje przy swych zarzutach, a sąd: Et domini receperunt ad interrogandum ad Regiam Maiestatem (Helc. II, 4483).

- w 1499 r. król udziela generalnego pelnomocnictwa procesowego Janowi ze Słupcy, w szczególności w procesie z Krzesławem z Kurozwęk, biskupem wloclawskim i kanclerzem koronnym (przedmiot sporu nie podany). (Helc. II, 4510).

b) król na drodze sądowej dochodzi uprawnień publicznych:

wykorzystuje droge procesową dla dochodzenia należności podatkowych. Do powolanej w artykule zapiski Helc. II, $1738 \mathrm{z} 1420 \mathrm{r}^{29}$ dodać należy, że w charakterze powodów występują król, sługa (famulus) starosty krakowskiego, sługa innej osoby, woźny sądowy - wszyscy określeni mianem detentores ${ }^{30}$.

- na drodze sądowej król występuje przeciwko naruszającemu postanowienia edyktu o drogach handlowych na Węgry ${ }^{31}$.

Wydaje się, że będąc stroną procesową, król respektowal zasadę nemo iudex in causa sua. Jednakże dwa przypadki pewne obawy budzą. Pierwszy to spór z 1498 r., w którym sąd nie może rozstrzygnąć kwestii, czy przypowiast jest sprawny, i odsyła ad interrogandum do króla będącego

${ }^{29}$ Zob. Z. R y maszewski, ,Domino Regi...", s. 323, ods. 38. Przeprowadzony tu podział działalności króla na forum sądowym pozostawia wiele do życzenia, czego dowodem są np. zastawy królewszczyzn, jednakże dla potrzeb tego artykułu jest on zasadny. Co do zastawu królewszczyzn i problemów związanych $z$ właściwym rozumieniem jego funkcji zob. szereg artykułów Jacka S. Matuszewskiego, w których autor podjałł trud prostowania szeregu pomylek i nieścisłości pojawiających się $w$ literaturze dotyczącej zwłaszcza ruchu egzekucyjnego. Zob. J. S. M a tu s ze wsk i, Czy pierwsi Jagiellonowie roztrwonili dobra królewskie, Sprawozdania z Czynności i Posiedzeń Naukowych LTN 1979, R. XXXIII, 6; t e nże, Egzekucja dóbr czy egzekucja dochodów?, Sprawozdania z Czynności i Posiedzeń Naukowych LTN $1986, \mathrm{R}$. XL, 6; t e nże, Postanowienia i realizacja ustawodawstwa zastawnego sejmów egzekucyjnych, Łódź 1986; t e nż e wraz z T. Szulcem, Opodatkowanie i polityka zastawu miast królewskich w Polsce Jagiellonów. Uwagi w zwiqzku z ksiqżkq Michaela Ludwiga, CPH 1989 , t. XLI, z. 2, s. 175-192.

${ }^{30} \mathrm{~W}$ AGZ jako powód $w$ sprawach podatkowych występuje woźny sądowy.

${ }^{31}$ Helc. II, 3874 z 1467 r.: Serenissimus dominus Rex Kazimirus d. g. R. P. nobilem Jacobum Trzeczeszky condempnavit pro eo, quia Serenissimus dominus Rex proclamare mandavit ministeriali non alia via ire in Hungariam, nisi per Sandecz vel Byecz, et ipse Jacobus contra mandatum Sue Serenitatis ministeriali precepit, hoc idem iterum reclamare alias; iuxta citacionem ministerialis prout idem recognovit. 
powodem w tej sprawie. Drugi: król-powód odsyła sprawę do Sanoka, ponieważ powiat sanocki jest propinquior dla pozwanych ${ }^{32}$.

Nie natrafiliśmy $w$ przejrzanych źródłach na tekst pozwu w sprawie, w której król występuje jako strona procesowa. Przynajmniej od konstytucji z 1511 r. dla króla i urzędu właściwe są wszystkie sądy ${ }^{33}$.

5. Reasumując, przegląd źródeł miejskich, kościelnych i szlacheckich daje właściwie te same wyniki. Rola króla w państwie jest przemożna. Liczne procesje zabiegających o wsparcie u króla świadczą, że był on istotnie traktowany jako ten, który pomocy nie odmawia i chętnie jej udziela. Widać też lęk przed nielaską królewską. Nie było chyba purpurata ani magnata, który by się jej nie lękał. A z laski królewskiej otrzymywało się wszelkie urzędy. Był też król wielkim feudałem, wielkim panem, uosobieniem państwa. Odnosi się nieodparte wrażenie, że w praktyce królowi polskiemu w porównaniu $\mathrm{z}$ francuskim brakowało tylko lettres de cachét.

Takie są wyniki badań cząstkowych, których potwierdzenie czy korekta mogłyby nastąpić dzięki studiom monograficznym, całościowym.

Temat jest zarówno interesujący, jak też ważny, kryje $z$ pewnością w sobie wiele niespodzianek.

${ }^{32}$ Helc. II, 2663 z 1436 r., in Curia Regis.

${ }^{33}$ Zob. Corpus Iuris Polonici, t. III, wyd. O. Balzer, Kraków 1906 [CIP] s. 154, kol. prawa, poz. 69. Statuta conventionis generalis, Piotrków 15.2.1511, p. 9. Poena contra evocantes quempiam extra proprium districtum. Item statuimus, ne quis audeat quempiam extra districtum suum evocare preter regiam et officii causam, que non habet districtum; contrarium faciens XVI marc. poena puniatur. 